Check for updates

Cite this: RSC Adv., 2019, 9, 17211

Received 30th March 2019

Accepted 14th May 2019

DOI: 10.1039/c9ra02397f

rsc.li/rsc-advances

\section{Procyanidin A2, an anti-diabetic condensed tannin extracted from Wendlandia glabrata, reduces elevated G-6-Pase and mRNA levels in diabetic mice and increases glucose uptake in CC1 hepatocytes and C1C12 myoblast cells $\uparrow$}

\author{
Yunush Sheikh, ${ }^{\mathrm{b}}$ Maibam Beebina Chanu, ${ }^{\mathrm{b}}$ Gopinath Mondal, ${ }^{\mathrm{b}}$ Prasenjit Manna, ${ }^{\mathrm{c}}$ \\ Asamanja Chattoraj, $\hat{t}^{\mathrm{b}}$ Dibakar Chandra Deka, ${ }^{\mathrm{d}}$ Narayan Chandra Talukdar ${ }^{\mathrm{a}}$ \\ and Jagat Chandra Borah (D) *a
}

\begin{abstract}
To reduce the global burden of diabetes in an affordable way great attention has been paid to the search for functional foods and herbal remedies. One of the most popularly used functional foods in the North Eastern region of India is tender shoots of Wendlandia glabrata DC. In the current study identification of active antidiabetic constituent of the tender shoots of $W$. glabrata was guided through $\alpha$-glucosidase inhibition and procyanidin $\mathrm{A} 2$ was identified with $\mathrm{IC}_{50} 0.27 \pm 0.01 \mu \mathrm{g} \mathrm{mL} \mathrm{L}^{-1}$ making it potential source for postprandial management of DM type 2. The study has also demonstrated procyanidin A2 as a potent anti-diabetic agent that exhibits significant glucose-6-phosphatase inhibitory activities and downregulated mRNA level in diabetic mice as well as increases glucose uptake in hepatocytes and myoblast cells. This study revealed that easily available tender shoots of $W$. glabrata could be used to make specific dietary recommendations for consumption for affordable management of diabetes.
\end{abstract}

\section{Introduction}

IDF Diabetes Atlas 2017 reveals an alarming 425 million people with diabetes worldwide, which is expected to reach 629 million by 2045 . The number is 82 million for South-East Asia and expected to reach 151 million by 2045 (IDF Diabetes Atlas, 2017). ${ }^{1}$ Type 2 diabetes is the leading cause of premature death due to related complications such as cardiovascular and chronic renal failure. ${ }^{2}$ At present there is urgent need for more concerted action to reduce the epidemic prevalence of diabetes. Indeed an intensified search is going on worldwide for local herbs, functional foods and ethnomedicines to combat diabetes. ${ }^{3}$

Dietary polysaccharides are important sources of blood glucose. One very vital enzyme that catalyses the conversion of

${ }^{a}$ Laboratory of Natural Medicinal Chemistry, Life Sciences Division, Institute of Advanced Study in Science \& Technology, Guwahati-781035, Assam, India. E-mail: jcborah03@yahoo.com; Fax: +91-361-2273063; Tel: +91-361-2273061

${ }^{b}$ Institute of Buioresources and Sustainable Development, Imphal-795001, Manipur, India

${ }^{c}$ CSIR-North East Institute of Science and Technology, Jorhat-785006, Assam, India

${ }^{d}$ Department of Chemistry, Gauhati University, Guwahati-781014, India

$\dagger$ Electronic supplementary information (ESI) available. See DOI: 10.1039/c9ra02397f

\$ At present Department of Animal Science, Kazi Nazrul University, Asansol, West Bengal-713340, India. polysaccharides into monosaccharides is $\alpha$-glucosidase (Ghani 2015). ${ }^{4}$ Therefore, it is highly imperative to develop food and/or herbal remedies and inhibitors that could slow down the activity of $\alpha$-glucosidase to control postprandial blood glucose levels. Also another potential target for treatment of diabetes type 2 is glucose-6-phosphatase (G-6-Pase) which catalyses the terminal step in gluconeogenesis and glycogenolysis to produce glucose. Reduction of blood glucose level by decreasing hepatic glucose production through down-regulation of G-6-Pase has been reported. ${ }^{5}$ Also increased protein content (G-6-Pase) and mRNA levels are reported in diabetic animals and contribute to the prevailing hyperglycemia. ${ }^{6-8}$ G-6-Pase inhibitors are considered as potential agents to reduce hepatic glucose production making it an attractive therapeutic target for the treatment of diabetes type 2 .

The tender shoots of Wendlandia glabrata DC have been used as functional foods in the North Eastern Region of India. W. glabrata, a flowering plant of the Rubiaceae family, is used as an ingredient of the indigenous salad Singju; people believe that it reduces obesity and controls blood sugar. It is also used for the treatment of dysentery and as an expectorant. ${ }^{9,10}$ In our previous study it is revealed the $\alpha$ glucosidase inhibitory potency and anti-hyperglycemic effects of the methanol extract of $W$. glabrata on STZ induced diabetes in albino rats. ${ }^{11}$ But phytochemical investigation and intensive study for treatment of diabetes are 
scarce in the literature. The facts encouraged us to take up further phytochemical investigation on the active antidiabetic constituent(s) of the tender shoots of W. glabrata and to study the inhibitory effects of the extractives on G-6Pase and glucose uptake by hepatocytes and myoblast cells. This led to the demonstration of procyanidin A2 (PCA2) as a potent anti-diabetic agent that exhibits significant $\alpha$ glucosidase inhibition, reduces increased level of protein content (G-6-Pase) and mRNA level in diabetic mice and also increases glucose uptake in both $\mathrm{CC} 1$ hepatocytes and $\mathrm{C} 2 \mathrm{C} 12$ myoblast cells.

\section{Results and discussion}

The $\alpha$-glucosidase inhibitory activities of the methanol extract of shoots of $W$. glabrata, subsequent EA, $n$-Bu, water fractions, EA SFr5 sub-fraction and isolated molecule PCA2 are presented in Table 1. Methanol extract and EA fraction exhibited potential inhibition with $\mathrm{IC}_{50} 1.67 \pm 0.33 \mu \mathrm{g} \mathrm{mL} \mathrm{m}^{-1}$ and $0.90 \pm 0.02 \mu \mathrm{g} \mathrm{mL}^{-1}$ respectively. The most potent sub fraction EA SFr 5 yielded PCA2 having significantly higher inhibitory potency with $\mathrm{IC}_{50} 0.46 \pm 0.01 \mu \mathrm{M}$. The increasing incidence of type 2 diabetes has fueled intensified search for natural $\alpha$-glucosidase inhibitors for future lead molecules or herbal preparations useful for treatment of diabetes. ${ }^{12,13}$ Significant $\alpha$-glucosidase inhibition by the methanol extract and compound PCA2 isolated thereof revealed the promising potential of the source for postprandial management of DM type 2.

PCA2 was isolated as a whitish brown powder. HRMS analysis showed protonated molecular ion peak at $\mathrm{m} / \mathrm{z}$ $577.1311[\mathrm{M}+\mathrm{H}]^{+}$. NMR data are presented in Table $2 .{ }^{1} \mathrm{H}$ NMR showed signals at $\delta 4.05(1 \mathrm{H}, \mathrm{d}, J=3.5, \mathrm{H}-3 \beta)$ and 4.40 $(1 \mathrm{H}, \mathrm{d}, J=3.0, \mathrm{H}-4 \beta)$, F-ring protons of A-type procyanidins. Two meta coupled signals at $\delta 6.00(1 \mathrm{H}, \mathrm{d}, J=2.5 \mathrm{~Hz}, \mathrm{H}-6 \beta)$ and $6.06(1 \mathrm{H}, \mathrm{d}, J=2.5 \mathrm{~Hz}, \mathrm{H}-8 \beta)$, and a singlet at $6.08\left(1 \mathrm{H}, \mathrm{H}^{-}\right.$ $6 \alpha$ ) as well as two ABX coupling systems around $\delta 6.81-7.14$ testified to a dimeric flavanol. $2 \beta-O-8$ Ether linkage is also supported by the location of one acetal carbon peak at $\delta$ 98.65. The observed HMBC and HMQC correlations (Table 2) are in good agreement for procyanidin A2 (PCA2) as reported in the literature.

Table 1 Half maximum inhibitory concentration $\left(\mathrm{IC}_{50}\right)$ against $\alpha$ Glucosidase $^{a}$

\begin{tabular}{lll}
\hline S. no. & Samples & $\mathrm{IC}_{50}\left(\mu \mathrm{g} \mathrm{mL}{ }^{-1}\right)$ \\
\hline 1 & MeOH extract & $1.67 \pm 0.33$ \\
2 & Ethyl acetate fraction & $0.90 \pm 0.02$ \\
3 & $n$-Butanol fraction & $2.87 \pm 0.02$ \\
4 & Water fraction & $5.67 \pm 0.29$ \\
5 & EA SFr5 & $0.74 \pm 0.04$ \\
6 & PCA2 & $0.27 \pm 0.01,(0.46 \pm 0.01)$ \\
7 & Acarbose & $378.73 \pm 0.08$
\end{tabular}

${ }^{a}$ Each value is the mean $\pm \mathrm{SD}(n=3)$. Data in parentheses are expressed in $\mu \mathrm{M}$.
Table $2{ }^{13} \mathrm{C},{ }^{1} \mathrm{H}$ and $\mathrm{HMBC}$ NMR data of PCA2 $\left(500 \mathrm{MHz}, \mathrm{CD}_{3} \mathrm{OD}\right.$, $\delta$ ppm)

\begin{tabular}{|c|c|c|c|}
\hline Position & ${ }^{13} \mathrm{C}$ & ${ }^{1} \mathrm{H}$ (HMQC) & $\operatorname{HMBC}(\mathrm{C} \rightarrow \mathrm{H})$ \\
\hline \multicolumn{4}{|l|}{$\alpha$ unit } \\
\hline 2 & 80.24 & 4.92 & $2.96,7.00,7.14$ \\
\hline 3 & 65.47 & 4.23 & 2.74 \\
\hline 4 & 28.39 & $2.96 \& 2.74$ & \\
\hline 5 & 155.09 & & \\
\hline 6 & 94.95 & 6.08 & \\
\hline 7 & 152.73 & & \\
\hline 8 & 105.69 & & 6.08 \\
\hline 9 & 150.79 & & \\
\hline 10 & 100.89 & & 2.96 \\
\hline $1^{\prime}$ & 129.69 & & 4.92 \\
\hline $2^{\prime}$ & 118.84 & 7.00 & $4.92,7.14$ \\
\hline $3^{\prime}$ & 114.51 & 6.81 & 7.00 \\
\hline $4^{\prime}$ & 145.25 & & 7.00 \\
\hline $5^{\prime}$ & 144.47 & & 6.81 \\
\hline $6^{\prime}$ & 114.13 & 7.14 & \\
\hline \multicolumn{4}{|l|}{$\beta$ unit } \\
\hline 2 & 98.65 & & 7.14 \\
\hline 3 & 66.56 & 4.05 & 4.40 \\
\hline 4 & 27.73 & 4.40 & \\
\hline 5 & 155.49 & & \\
\hline 6 & 96.76 & 6.00 & \\
\hline 7 & 156.61 & & \\
\hline 8 & 95.09 & 6.06 & \\
\hline 9 & 150.63 & & \\
\hline 10 & 102.73 & & 4.05 \\
\hline $1^{\prime}$ & 130.93 & & 6.81 \\
\hline $2^{\prime}$ & 118.26 & 7.00 & 7.14 \\
\hline $3^{\prime}$ & 114.09 & 7.14 & \\
\hline $4^{\prime}$ & 144.78 & & 7.00 \\
\hline $5^{\prime}$ & 144.14 & & \\
\hline $6^{\prime}$ & 114.40 & 6.81 & \\
\hline
\end{tabular}

Effects of PCA2 on STZ induced diabetic Swiss albino mice at different dose and time intervals are presented in the Table 3. Diabetic mice were treated with three different doses $(10,25$ and $50 \mathrm{mg} \mathrm{kg}{ }^{-1}$ b.w.) of PCA2. The molecule showed dramatic glucose lowering effect $\left(115.0 \pm 19.08 \mathrm{mg} \mathrm{dL}^{-1}\right)$ when tested at $50 \mathrm{mg} \mathrm{kg}{ }^{-1}$ b.w. dose level for 14 days; the figure was significantly higher in diabetic mice $\left(379.7 \pm 60.87 \mathrm{mg} \mathrm{dL}^{-1}\right)$. The corresponding figure for the standard drug metformin $(50 \mathrm{mg}$

Table 3 Effect of PCA2 on blood glucose levels on STZ-induced diabetic mice ${ }^{a}$

\begin{tabular}{llcl}
\hline & \multicolumn{3}{l}{ Blood glucose $\left(\mathrm{mg} \mathrm{dL}{ }^{-1}\right)$} \\
\cline { 2 - 4 } Group $\left(\mathrm{mg} \mathrm{kg}^{-1}\right)$ & 1 st day & 7th day & 14th day \\
\hline Normal control & $89.20 \pm 12.01$ & $103 \pm 21.70$ & $98.00 \pm 26.66$ \\
Diabetic control & $306.8 \pm 67.90$ & $350.0 \pm 45.31$ & $379.7 \pm 60.87$ \\
Metformin (50) & $351.8 \pm 58.27$ & $191.0 \pm 11.14^{* *}$ & $107.7 \pm 16.44^{* * *}$ \\
PCA2 (10) & $336.0 \pm 95.24$ & $195.7 \pm 50.29^{* *}$ & $190.7 \pm 76.12^{* *}$ \\
PCA2 (25) & $297.0 \pm 76.92$ & $222.0 \pm 54.95^{*}$ & $153.7 \pm 22.14^{* * *}$ \\
PCA2 (50) & $308.6 \pm 51.08$ & $236.3 \pm 22.03^{*}$ & $115.0 \pm 19.08^{* * *}$
\end{tabular}

${ }^{a}$ Each value is the mean $\pm \mathrm{SD}(n=6) .{ }^{*} p<0.05 v s$. diabetic control. 
Table 4 Effect of PCA2 on biochemical parameters on STZ-induced diabetic mice ${ }^{a}$

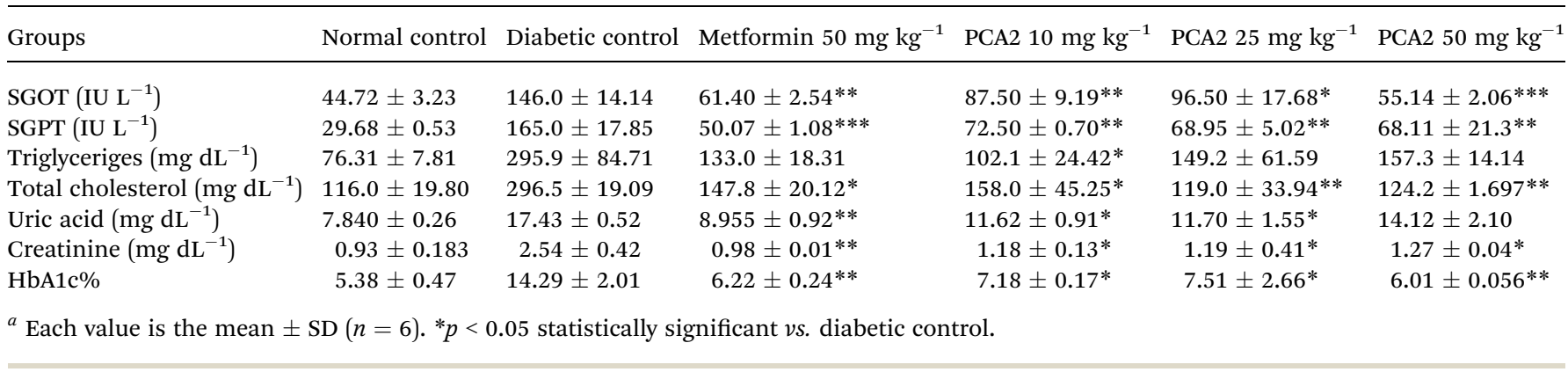

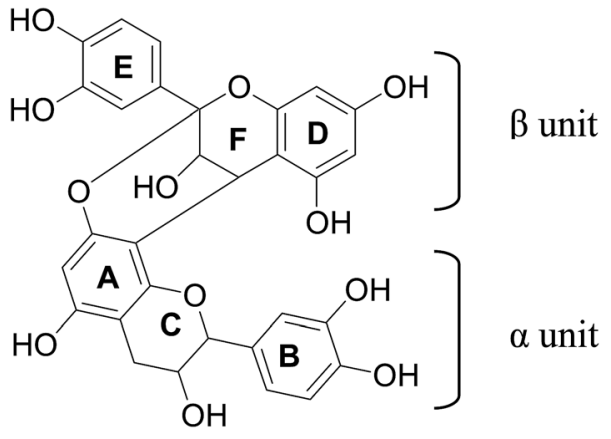

Fig. 1 Procyanidin A2.

$\mathrm{kg}^{-1}$ b.w.) was $107.7 \pm 16.44 \mathrm{mg} \mathrm{dL} \mathrm{d}^{-1}$. Thus glucose lowering effect of PCA2 in diabetic mice has been found to be as significant as that of metformin $(p<0.001)$.

The results obtained with the serum of mice having STZ induced diabetes are shown in Table 4. Upon treatment with STZ, higher level of HbA1c is observed compared to normal mice. No desired decrease of HbA1c to normal level was observed when mice were treated with $50 \mathrm{mg} \mathrm{kg}^{-1}$ b.w. of PCA2, this is probably due to study period (14 days) is not adequate to measure HbA1c.

STZ induces hepatocellular damage to liver which causes leakage of the hepatocellular enzymes, viz. SGOT and SGPT into the blood. In the current study significant increase in SGOT $\left(146.0 \pm 14.14 \mathrm{U} \mathrm{L}^{-1}\right)$ and SGPT $\left(165.0 \pm 17.85 \mathrm{U} \mathrm{L}^{-1}\right)$ were observed in diabetic mice which were substantially reduced $(p<0.001)$ when treated with PCA2 at $50 \mathrm{mg} \mathrm{kg} \mathrm{kg}^{-1}$ b.w.

Diabetes is also associated with elevated levels of total cholesterol and triglycerides which are the primary factors involved in the intensification of coronary heart disease and atherosclerosis, the secondary complications involved in diabetes. Dyslipidemia was observed with diabetic control animals compared to normal control group. Both TG and TC in diabetic control group were significantly higher. Significant reductions in TG and TC were observed with all the three doses $\left(10,25\right.$ and $\left.50 \mathrm{mg} \mathrm{kg}^{-1}\right)$ of PCA2. Compared with diabetic control, elevated levels of uric acid and creatinine were reduced substantially after treatment with PCA2 (Fig. 1).
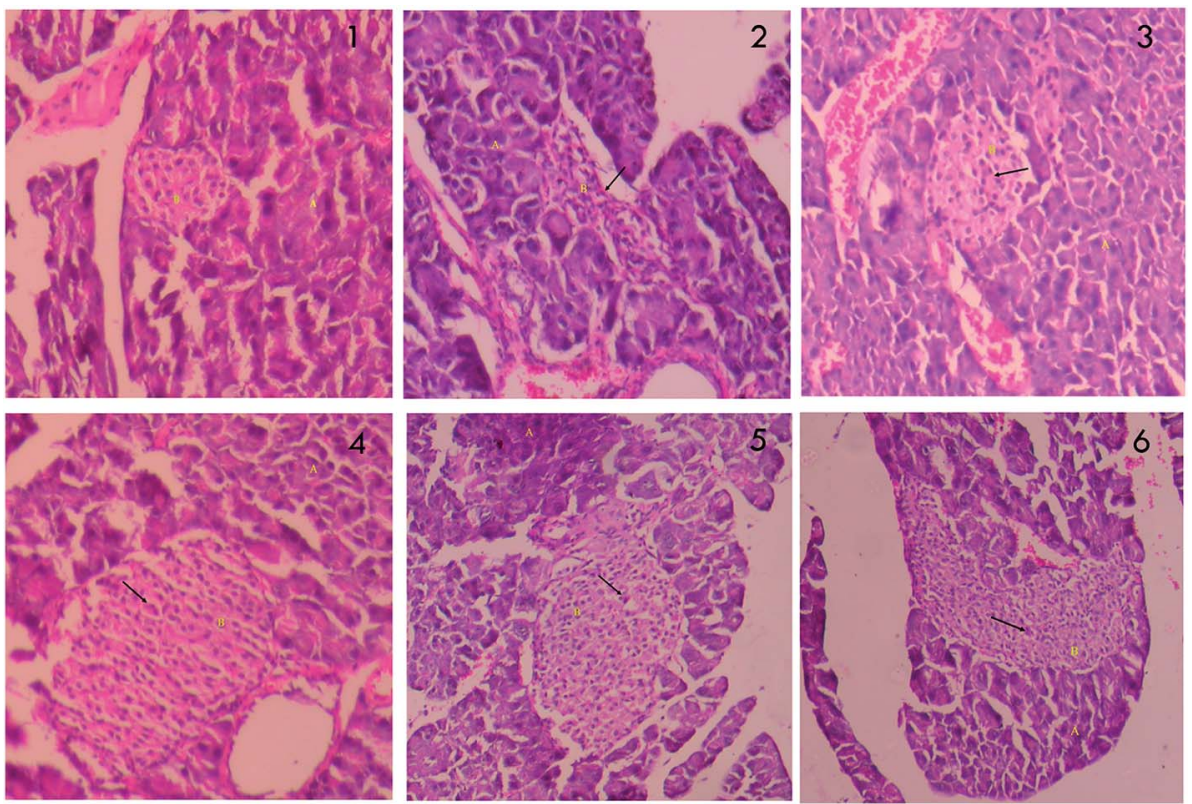

Fig. 2 Histopathology of pancreas; (1) normal control (2) diabetic control (STZ) (3) positive control (metformin) (4) PCA2 $10 \mathrm{mg} \mathrm{kg}^{-1}$ (5) PCA2 $25 \mathrm{mg} \mathrm{kg}^{-1}$ and (6) PCA2 $50 \mathrm{mg} \mathrm{kg}^{-1}$. 

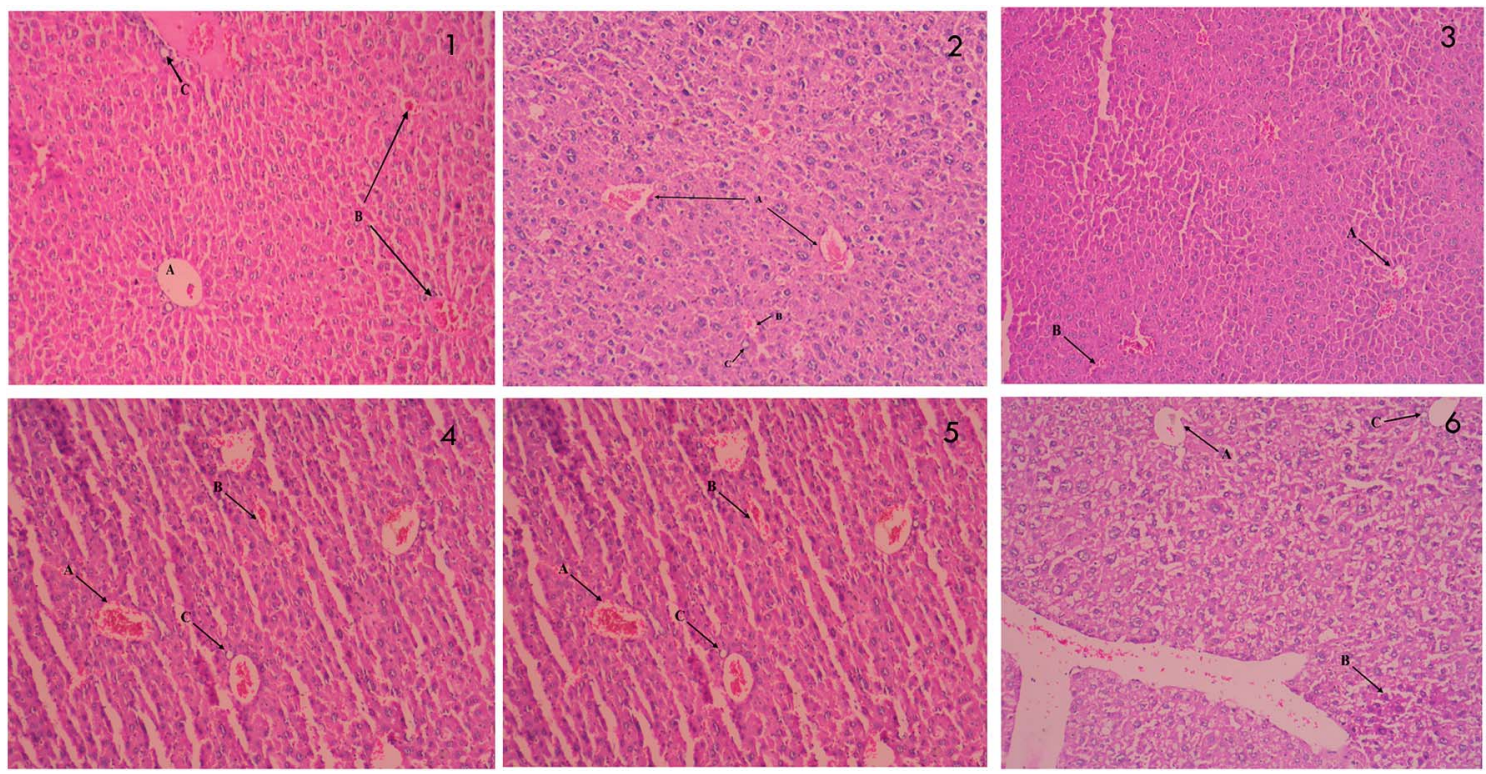

Fig. 3 Histopathology of liver; (1) normal control (2) diabetic control (STZ) (3) positive control (metformin) (4) PCA2 $10 \mathrm{mg} \mathrm{kg}^{-1}$ (5) PCA2 $25 \mathrm{mg}^{2}$ $\mathrm{kg}^{-1}$ and (6) PCA2 $50 \mathrm{mg} \mathrm{kg}^{-1}$

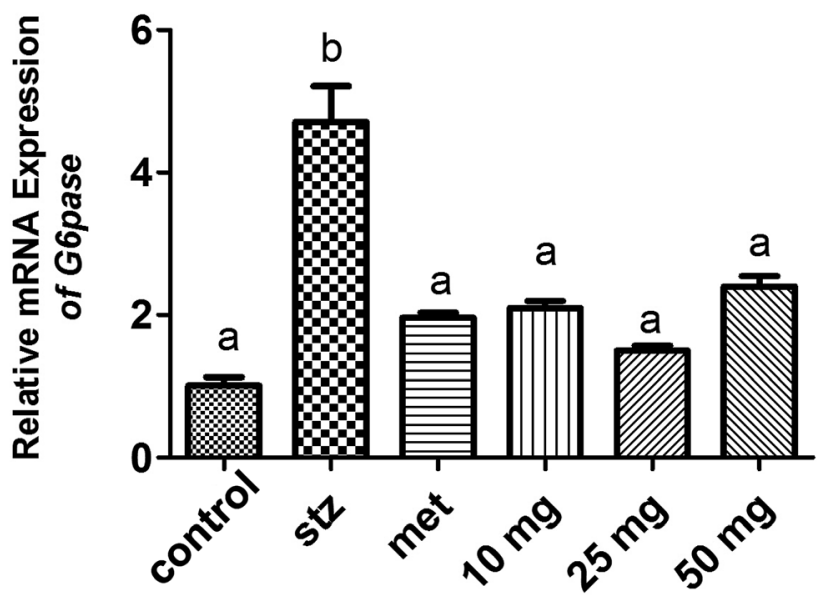

Fig. 4 Expression level of G-6-Pase in the hepatic tissue of mouse in various experimental groups. Different letters represent significant difference as determined by ANOVA followed by Tukey's post hoc test $(P$-value $<0.05)$.

The changes in histopathology of pancreas are showed in Fig. 2. The acinar cells around the islets of STZ treated pancreas (2) do not appear classical. The surrounding capsules of pancreatic $\beta$ cells are damaged, with reduction in the size of islets, and $\beta$ cells are largely occupied by inflammatory cells and eosinophilic material. Infiltration of lymphocytes is also seen. The acinar cells look normal with reduced inflammation when treated with metformin (3). PCA2 caused restoration of the necrotic cells and increase in the number and size of the pancreatic $\beta$ cells, with considerable reduction in lesions $(4,5$ and 6$)$.

The results of histopathological examinations of liver are presented in Fig. 3. Normal hepatic architecture was
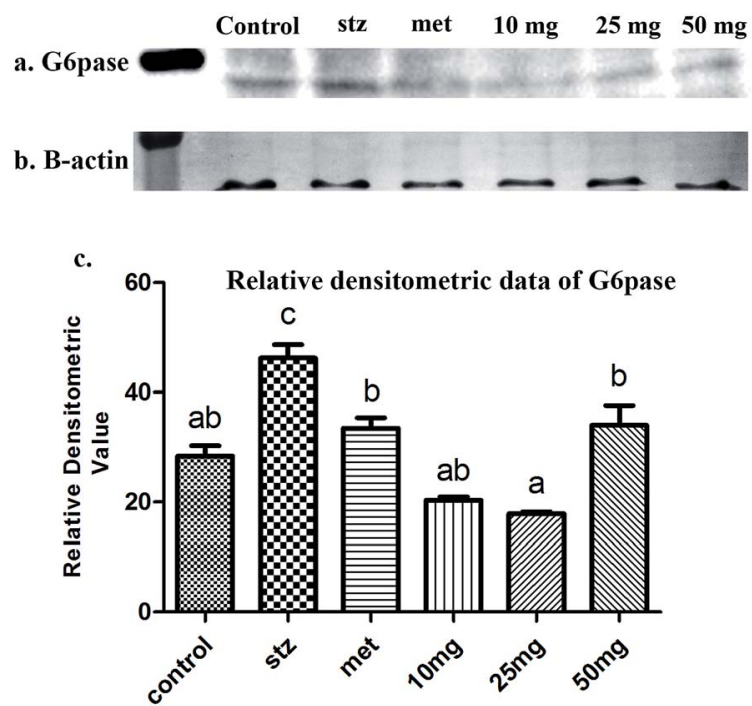

Immunoblot expression of G6pase and B-actin

Fig. 5 Immunoblots of (a) G-6-Pase and (b) $\beta$-actin proteins detected in the liver homogenate of mice $(n=6)$ under different experimental conditions. (c) Diagrammatic presentation of relative densitometric value of G6pase with reference to $\beta$-actin expression. Different letters represent significant difference as determined by ANOVA followed by Tukey's post hoc test $(P$-value $<0.05)$.

observed in control mice. Stern pathological changes such as necrotic damage of central and portal veins and shrinkage in hepatic arteries are seen in STZ treated mice (2). These histopathological changes are significantly alleviated when treated with different doses of PCA2 and the architecture was similar to that of metformin treated and normal mice. 

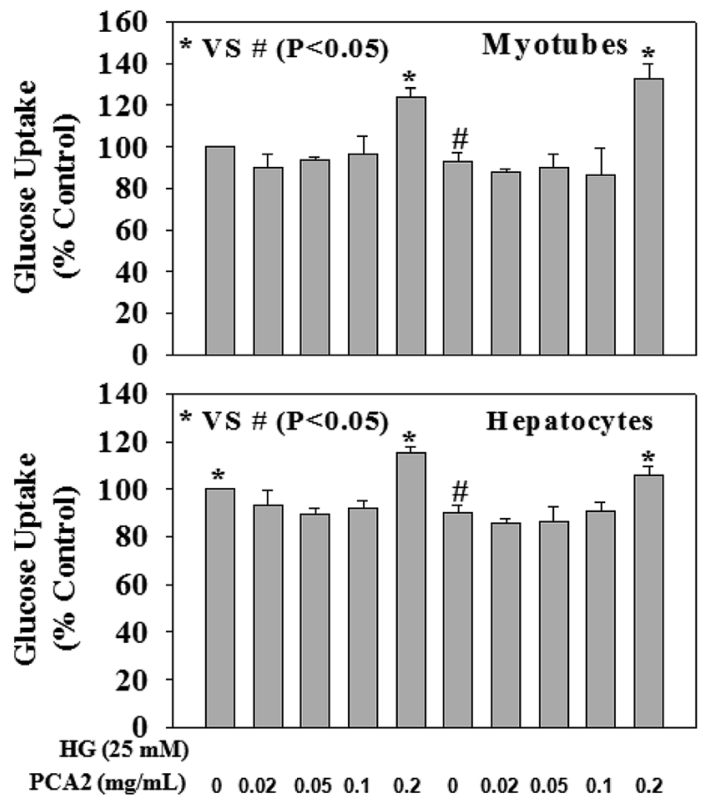

Fig. 6 Effect of PCA2 on cellular glucose uptake in myotubes (upper panel) and hepatocytes (lower panel). Cells were pre-treated with PCA2 for 2 hours followed by high glucose (HG, $25 \mathrm{mM}$ ) exposure for next 24 hours. Values are mean \pm SD $(n=4)$. Different letters represent significant difference as determined by ANOVA followed by Tukey's post hoc test $(P$-value $<0.05)$.

qRT-PCR analysis and Western-blot data demonstrated a basal level expression of hepatic G-6-Pase in untreated mice at the level of mRNA and protein respectively (Fig. 4 and 5). G6-Pase was higher in mice exposed to streptozotocin as compared to control animals both at transcriptional as well as translational levels. On the other hand, animals treated with metformin displayed decreased mRNA and protein levels as compared with the streptozotocin treated group. Furthermore, G-6-Pase expression was also reduced at the levels of both mRNA and protein, when treated with PCA2. Interestingly, mRNA expression of G-6-Pase came to a basal level when animals were treated with PCA2 and metformin (Fig. 4). However, lowest expression of G-6-Pase protein was observed with $25 \mathrm{mg}$ dose of PCA2, which was significantly lower than that of metformin treatment (Fig. 5). It was also noted that further increase in the dose of the compound did not result in a dose-dependent reduction in the protein expression (Fig. 5). At $25 \mathrm{mg}$, the molecule PCA2 was found to be more effective than metformin at protein level. The results revealed that one of the possible modes of action may be the lowering of hepatic glucose by inhibition of G-6-Pase.

Interestingly, the ESI Fig. $1 \uparrow$ reveals that change in enzyme activity after the treatment of metformin and various concentration of the PCA2 are statistically equivalent. Moreover, comparative analysis of Fig. 4, 5, Table 3 and ESI Fig. $1 \dagger$ supports the findings that the specific enzymatic activity is dependent on the chemical properties of the enzyme and the concentration of enzyme is directly affected by degradation. ${ }^{14}$ Genetic mutations, epigenetic modifications, transcriptional and translational regulation, post transcriptional and post-translational modification, and protein degradation leads to differential enzyme activity and thus, maintain the cellular heterogeneity.

Fig. 6 demonstrates the effect of PCA2 on cellular glucose uptake in hepatocyte and myotube cells against HG exposure. HG exposure caused a decrease in glucose uptake in both cells. Treatment with PCA2 at a dose of $0.2 \mathrm{mg} \mathrm{mL}^{-1}$ significantly increased glucose uptake in both cells compared to those seen in HG-treated cells. Interestingly, treatment of control cells with PCA2 also enhanced the cellular glucose uptake at a dose of $0.2 \mathrm{mg} \mathrm{mL}^{-1}$ compared to untreated cells. This study suggests a beneficial role of PCA2 on intracellular glucose metabolism. The cell proliferation assay was performed by using alamar blue reduction bioassay (Himedia, India) and the results showed that different treatments did not cause any significant change in cell proliferation compared to those seen in untreated group (data not given).

There is substantial evidence that elevated hepatic glucose production is responsible for type 2 diabetes. The liver both stores and manufactures glucose depending upon the body's need. It makes sugar through gluconeogenesis and glycogenolysis, two important metabolic pathways. In both the processes the terminal step, which is catalyzed by the enzyme G-6-Pase primarily located in the liver, involves conversion of glucose-6-phosphate (G-6-P) to glucose and inorganic phosphate. ${ }^{15-17}$ Increased level of G-6-Pase content and mRNA levels has been revealed in diabetic animals causing hyperglycaemia. In the current study, PCA2 substantially reduced the elevated G-6-Pase protein content and mRNA level, making it a potential G-6-Pase inhibitor to reduce hepatic glucose production.

One of the major causes associated with chronic hyperglycemia is the failure of peripheral tissues to properly utilize

Table 5 List of primer used for real-time $\mathrm{qPCR}^{a}$

\begin{tabular}{llll}
\hline Genes & Primer sequence & $\begin{array}{l}\text { Amplicon } \\
\text { size }\end{array}$ & Accession number \\
\hline G6pase & F: TGGTAGCCCTGTCTTTCTTTG & 90 & NM_008061.4 \\
Rplpo & F: GCAGGTGTTCACACTTCCT & & NM_007475.5 \\
& R: GATGATGGAGTGTGGCACCGA
\end{tabular}

${ }^{a}$ Primer sequences for real-time quantitative RT-PCR assays of target and reference genes. F, forward; R, reverse. *Accession number is provided by the National Centre for Biotechnology Information, Bethesda, MD, USA. References have been given in the text. 
glucose. In our study, significantly increased glucose uptake has been observed in both the cells when treated with PCA2 compared to untreated and HG treated hepatocyte and myotube cells.

\section{Conclusions}

This study indicated the role of young shoots of $W$. glabrata and PCA2 isolated thereof in the management of diabetes and this may be used to make specific dietary recommendations regarding consumption. Anti-hyperglycemic effect of PCA2 combined with our observations at protein and mRNA level suggests that reduction in glucose level may be due to lowering of hepatic glucose production and/or stimulated insulin release followed by uptake by liver and muscle cells leading to decrease plasma glucose concentration. The findings assume particular significance as proanthocyanidin A type phenolics are reported to possess a broad spectrum of health benefits, ${ }^{18-21}$ foods containing proanthocyanidins reduce the risk of cardiovascular diseases, cancer, blood clotting, and protect against urinary tract infections. ${ }^{22-26}$ For the first time phyto-chemical investigations of the tender shoots of $W$. glabrata revealed active constituent PCA2 and support its use as traditional medicine for management of diabetes by the suggested lowering hepatic glucose production.

\section{Experimental}

\section{Chemicals and instruments}

Combiflash $\mathrm{R}_{\mathrm{f}}$ 200i (Teledyne ISCO) fitted with glass column and silica gel $60 \mathrm{RP}-18(40-63 \mu \mathrm{m})$ were used for purification of fractions. Shimadzu HPLC, LC 20AD with PDA detector fitted with either an analytical column (Discovery RP Amide C-16 Supelco $5 \mu \mathrm{m} 250 \times 4.6 \mathrm{~mm}$ ) or semi-preparative (Discovery Amide C-16 Supelco $5 \mu \mathrm{m} 250 \times 10 \mathrm{~mm}$ ) were used for analysis and purification of compounds. Column chromatography was carried out with Merck silica gel (100-200 mesh size). Thin layer chromatography (TLC) was done on TLC plates pre-coated with silica gel 60F254 (0.25 mm normal phase Merck). $\alpha$-Glucosidase (Maltase EC 3.2.1.20) and $p$-nitro phenyl- $\alpha$-D-glucopyranoside were purchased from Sisco Research Laboratory (SRL). Streptozotocin was purchased from Sisco Research Laboratories, Mumbai and metformin from Sigma Aldrich USA. 6-NBDG was procured from Invitrogen. NMR spectra were recorded on a Bruker Avance $500 \mathrm{MHz}$ instrument with TMS as internal standard. Chemical shifts are expressed in $\delta$ values. Agilent 6520 Accurate mass Q-TOF/LC-MS was used to determine molecular weight. Absorbance was measured by Thermo Scientific Multiskan spectrometer. All other chemicals and reagents were of analytical grade.

\section{Plant material}

Fresh tender shoots of Wendlandia glabrata DC were collected from Kangla Shiphai, Imphal, Manipur, India in the month of April and the identification was authenticated in the Institute of Bioresources and Sustainable Development, Imphal, India. A voucher Specimen was deposited in the Herbarium and number is IBSD/M-199.

\section{Extraction and isolation}

The shade dried shoots $(4.4 \mathrm{~kg})$ of $W$. glabrata were ground into powder of mesh size 50 . The dried powder was extracted at room temperature with $\mathrm{MeOH}$ three times at $24 \mathrm{~h}$ intervals and the extracts were combined to yield $400 \mathrm{~g}$ of crude $\mathrm{MeOH}$ extract. A part of the extract ( $100 \mathrm{~g})$ was suspended in water (400 $\mathrm{mL})$ and fractionated using ethyl acetate $(800 \mathrm{~mL} \times 2)$ and $n$ butanol $(800 \mathrm{~mL} \times 2)$. All the fractions were dried in rotary evaporator to obtain $18.53 \mathrm{~g}$ of ethyl acetate fraction (EAFr), $40.63 \mathrm{~g}$ of $n$-butanol fraction (BuFr) and $35.83 \mathrm{~g}$ of water fraction (WFr). Further purification of the fractions was guided by $\alpha$ glucosidase inhibition potential. The most potent fraction EAFr (15 g) was further fractionated using a silica gel column into five sub-fractions with the increasing polarities using $3: 1 \mathrm{PE}: \mathrm{CHL}$ (800 mL, EA SFr 1), $1: 1$ PE : CHL (1000 mL, EA SFr 2), CHL (1000 mL, EA SFr 3), $9: 1 \mathrm{CHL}: \mathrm{MeOH}$ (1500 mL, EA SFr4), and 4 : 1 CHL : MeOH $(1500 \mathrm{~mL}$, EA SFr 5). The most active subfraction 5 (EA SFr 5, $4.25 \mathrm{~g}$ ) was subjected to further purification using semi-preparative HPLC to obtain PCA2.

\section{$\alpha$-Glucosidase inhibitory assay}

$\alpha$-Glucosidase inhibition assay was performed in 96-well corning flat bottom plate model following previously reported method. ${ }^{27}$ The test sample was dissolved in DMSO and diluted in $0.1 \mathrm{M}$ phosphate buffer ( $\mathrm{pH}$ 6.8) to get the desired test concentration per well. A solution $\left(0.5 \mathrm{U} \mathrm{mL}^{-1}\right)$ of $\alpha$-glucosidase in $0.1 \mathrm{M}$ phosphate buffer $(\mathrm{pH} 6.8,25 \mu \mathrm{L})$ was added to it and incubated at $37{ }^{\circ} \mathrm{C}$ for $10 \mathrm{~min}$. A solution of $p$-nitrophenyl- $\alpha$-Dglucopyranoside (PNPG) in 0.1 M phosphate buffer (pH 6.8, 25 $\mu \mathrm{L}$ ), which acted as substrate, was added after $10 \mathrm{~min}$ incubation and further incubated at $37^{\circ} \mathrm{C}$. After $30 \mathrm{~min}$ incubation the enzyme reaction was stopped by the addition of sodium carbonate $(0.1 \mathrm{M})$ and the amount of $p$-nitrophenol released was monitored at $405 \mathrm{~nm}$. Blanks comprised of buffer and substrate was employed. DMSO was used as control, maintaining the final concentration at $2 \% \mathrm{v} / \mathrm{v}$. Acarbose was used as positive control. All the experiments were performed in triplicate in three independent experiments. The $\%$ inhibition of $\alpha$-glucosidase was calculated by the following formula:

$$
\begin{aligned}
\% \text { inhibition }= & \left(\text { absorbance }_{\text {control }}-\text { absorbance }_{\text {treatment }}\right) \\
& \text { /absorbance }_{\text {control }} \times 100 .
\end{aligned}
$$

\section{Experimental animals}

Swiss albino mice of both sexes (20-30 g) were procured from Regional Institute of Medical Sciences (RIMS), Manipur, India. Ethical clearance was obtained from the Institutional Animals Ethical Committee (approval no.-IBSD/IAEC/Inst./NPC/22). Animals were kept in standard polypropylene cages (six mice/ cage) lined with husk under standard environmental condition with 12/12 h light/dark cycle. They were fed standard diet 
(Nutrilab, Provimi, Bangalore, India) and kept for one week acclimatization before conducting the experiments, also provided water ad libitum for the duration of experiment.

\section{Acute toxicity test}

Acute toxicity study was performed as per OECD guideline no. 423 (Annexure-2c) adopted by CPCSEA, Government of India. Fasted three mice in a group initially given oral dose of $2000 \mathrm{mg}$ $\mathrm{kg}^{-1}$ b.w. of PCA2 and observed periodically for $24 \mathrm{~h}$. Other common side effects such as weight lose, mild diarrhoea and depression were monitored for 14 days.

\section{Anti-hyperglycemic assay}

Diabetes was induced in overnight fasted mice by single intraperitoneal (i.p.) injection of $150 \mathrm{mg} \mathrm{kg} \mathrm{kg}^{-1}$ of streptozotocin (freshly dissolved in $0.1 \mathrm{M}$ citrate buffer, $\mathrm{pH} 4.5$ ). After $1 \mathrm{~h}$, the animals were provided with $5 \%$ glucose solution (p.o.) for the next $2 \mathrm{~h}$ to protect from hypoglycaemic shock. Animals showing marked hyperglycemia (fasting blood glucose $\geq 200 \mathrm{mg} \mathrm{dL}^{-1}$ ) $48 \mathrm{~h}$ after STZ treatment were considered diabetic and selected for the study. Experimental mice were divided into six groups of six animals each. Group 1 treated with $0.5 \% \mathrm{v} / \mathrm{v}$ Tween 80 served as normal control, Group 2 served as diabetic control, and Group 3 treated with metformin $\left(50 \mathrm{mg} \mathrm{kg}^{-1}\right)$ as positive control; Groups 4, 5 and 6 were treated with PCA2 at three different doses of 10,25 and $50 \mathrm{mg} \mathrm{kg}^{-1}$ b.w. respectively (administration by oral gavage). Fasting blood glucose levels were monitored (tail prick) weekly using ACCU-CHEK Active (Roche Diagnostics GmbH, Germany). At the end of 14th day blood was collected through retro orbital and cardiac puncture for biochemical parameter analysis. Pancreas and liver were dissected out for further study and histopathological examination. Glucose-6-phosphatase expression was studied by western blotting and mRNA expression in qRT-PCR.

\section{Biochemical parameters analysis}

Serum was separated by centrifugation at $3500 \times g$ for $10 \mathrm{~min}$. All biochemical tests were carried out using commercial kits obtained from Erba diagnostic, Mannheim Gmbh, Germany using Erba Mannheim semi automatic biochemistry analyser. HbA1c was analysed using whole blood, while SGOT, SGPT, triglyceride and total cholesterol were analysed using serum.

\section{Glycated haemoglobin ( $H b A 1 c)$}

HbA1c was determined according to the manufactures' guidelines by using commercial kits from Erba diagnostic Mannheim Gmbh, Germany using Erba Mannheim semi automatic biochemistry analyser. Whole blood was haemolysed and mixed with a weak binding cation-exchange resin, continuously for 5 min. Non-glycosylated haemoglobin bound to the resin and the supernatant containing glycohaemoglobin was separated with a filter. Glycosylated haemoglobin (\%) was determined by measuring the ratio $(R)$ of absorbances of glycohaemoglobin fraction and the total haemoglobin fraction at $415 \mathrm{~nm}$ using the following equation:
$\%$ glycohaemoglobin of unknown $=\frac{R_{\mathrm{u}}}{R_{\mathrm{c}}} \times$ value of calibrator

$$
\begin{aligned}
& R_{\mathrm{u}}=\frac{\text { absorbance of calibrator }(\text { glyco })}{\text { absorbance of calibrator }(\text { total })} \\
& R_{\mathrm{c}}=\frac{\text { absorbance of unknown }(\text { glyco) }}{\text { absorbance of unknown (total) }}
\end{aligned}
$$

\section{Liver function analysis}

Liver function test enzymes, viz. serum glutamic oxaloacetic transaminase (SGOT) and serum glutamic-pyruvic transaminase (SGPT) were determined by using commercial kits from Erba diagnostic Mannheim Gmbh. An aliquot $(100 \mu \mathrm{L})$ of test serum was mixed well with $1000 \mu \mathrm{L}$ of respective reagent [reagent after reconstitution with aqua contained 2-oxoglutarate, L-Aspartate, $\mathrm{MDH}, \mathrm{LDH}, \mathrm{NADH}$ (yeast), Tris buffer and EDTA (for SGOT and L-alanine), NADH (Yeast), LDH, 2-oxoglutarate and Tris buffer for SGPT] and absorbance was measured.

\section{Serum lipid profile}

Serum cholesterol and triglycerides were determined by using commercial kits from Erba diagnostic Mannheim Gmbh, Germany. The test serum $(20 \mu \mathrm{L})$ was mixed with $1000 \mu \mathrm{L}$ of the respective working reagent (reagent after reconstitution with aqua contained cholesterol esterase, cholesterol oxidase, peroxidase, sodium phenolate, 4-aminoantipyrine, phosphate buffer for cholesterol and ATP, $\mathrm{Mg}^{2+}$, 4-aminoantipyrine, 3,5 DHBS, glycerol kinase, GPO, lipoprotein lipase, and buffer for triglycerides), incubated for $10 \mathrm{~min}$, and the absorbance was measured. In both the cases, the final product after a number of reactions is quinoneimine, whose level is proportional to the concentration of cholesterol and triglycerides.

\section{Histopathological study}

Whole pancreas and liver were removed immediately from all the animals and kept in $10 \%$ formalin solution for histopathological work. ${ }^{28}$

\section{RNA extraction and cDNA synthesis}

Sample for quantitative reverse transcriptase-polymerase chain reaction (qRT-PCR) were taken in RNAlater (Life technology, USA), and in $-80{ }^{\circ} \mathrm{C}$. The collection of control samples was done simultaneously with the experimental one. Total RNA was isolated from homogenized liver of mouse with Trizol reagent (Life technologies, USA) following the manufacturer's protocol. RNA pellets were eluted in RNase-free water (DEPC water, SigmaAldrich, USA). RNA quality and quantity were measured by using a Nano Spectra (Shimadzu, Japan). Afterwards, $5 \mu \mathrm{g}$ of total RNA was treated with DNA-free ${ }^{\mathrm{TM}}$ Kit (Ambion) to remove genomic DNA contamination. RNA integrity was checked by staining $28 \mathrm{~S}$ and 18S RNA bands with GelRed ${ }^{\mathrm{TM}}$ (Biotium, USA) 
nucleic acid stain on $0.8 \%$ agarose gel. DNase treated total RNA $(1 \mu \mathrm{g})$ was reverse transcribed into cDNA using "High Capacity cDNA Reverse Transcription Kit” (Applied Biosystems) according to manufacturer's instruction. cDNA synthesis was carried out in "ProFlex ${ }^{\mathrm{TM}}$ PCR System" (Applied Biosystems) following the manufacturer's protocol. Briefly, the reaction mixture contained $2 \mu \mathrm{L} 10 \times$ RT buffer, $0.8 \mu \mathrm{L} 10 \mathrm{mM}$ dNTP mix, $2 \mu \mathrm{L} 10 \times \mathrm{RT}$ primer, $1 \mu \mathrm{L}$ MultiScribe Reverse Transcriptase $\left(50 \mathrm{U} \mu \mathrm{L}^{-1}\right), 1 \mu \mathrm{L}$ RNase Inhibitor $\left(20 \mathrm{U} \mu \mathrm{L}^{-1}\right)$, and $10 \mu \mathrm{L}$ DNase treated RNA (liver), and the final volume was made up to $20 \mu \mathrm{L}$ by nuclease free water. The conditions for PCR cycling for cDNA synthesis were $25^{\circ} \mathrm{C}$ for $10 \mathrm{~min}$, followed by $37^{\circ} \mathrm{C}$ for $2 \mathrm{~h}, 85^{\circ} \mathrm{C}$ for $5 \mathrm{~min}$ and final incubation at $4{ }^{\circ} \mathrm{C}$.

\section{Real-time quantitative PCR (qRT-PCR)}

Expression level of the gene was measured by qRT-PCR using Jumpstart SYBR Green/ROX qPCR Master Mix (Sigma-Aldrich, USA). Real time PCR was carried out on an StepOnePlus Real time PCR system (Applied Biosystems, Inc, ABI, USA). Primers (Table 5) were synthesized from IDT, India as per the published data. ${ }^{29}$ The PCR reaction condition includes an initial denaturation step at $95{ }^{\circ} \mathrm{C}$ for $10 \mathrm{~min}$, followed by 40 cycles of $15 \mathrm{~s}$ at $95^{\circ} \mathrm{C}$, annealing at $60^{\circ} \mathrm{C}$ for $30 \mathrm{~s}$, and extension at $72{ }^{\circ} \mathrm{C}$ for $30 \mathrm{~s}$. Melting curve analysis $\left(T_{\mathrm{m}}\right)$ was performed to confirm single gene amplification by designated primers. Amplification was performed in $10 \mu \mathrm{L}$ reaction volume containing forward and reverse primers, qPCR Master Mix and cDNA. Technical triplicates were used for each sample. The relative expression of the gene was calculated by $2[-$ Delta Delta $\mathrm{C}(\mathrm{T})]$ method using Rplpo gene as ref. 30 and 31 .

\section{Western blot analysis}

At the time of sampling, mouse liver was removed and stored in RIPA buffer with protease inhibitor (Promega, USA) at $-80^{\circ} \mathrm{C}$. It was then thawed on ice, sonicated with 10-15 short bursts on a sonicator (SONICS, Vibra cell, USA), and centrifuged (Centrifuge 5430R, Eppendorf, Germany) at $30000 \times g$ for $20 \mathrm{~min}$ in microfuge at $4{ }^{\circ} \mathrm{C}$. The resulting supernatant was carefully collected in $1.5 \mathrm{~mL}$ microfuge tube and protein was estimated (RC DC protein assay, Bio-Rad Laboratories). The sample (60 $\mu \mathrm{g}$ of protein) was mixed with 2 X SDS sample buffer at a $1: 1$ ratio, boiled at $95{ }^{\circ} \mathrm{C}$, cooled on ice for $5 \mathrm{~min}$, separated on a $12 \%$ SDSPAGE gel, and further transferred on to a $0.45 \mu \mathrm{m}$ PVDF (Immobilion, Millipore, India) membrane. Membrane blocking was performed at $4{ }^{\circ} \mathrm{C}$ in blocking solution (5\% non-fat milk in TBST buffer: $50 \mathrm{mM}$ Tris, $100 \mathrm{mM} \mathrm{NaCl}, 0.1 \%$ Tween 20, pH 7.4) overnight. $^{32}$ The membranes were then washed with TBST buffer and incubated with primary antibodies: G6PASE (Santa Cruz, sc-25840, 1 : 1000 dilution) and $\beta$-actin (Ambion-AM4302, $1: 5000$ dilution) in the blocking solution overnight. They were then washed with TBST buffer and incubated for $1 \mathrm{~h}$ at room temperature with alkaline phosphatase conjugated secondary antibody (Sigma, 1 : 5000 dilution, goat anti-rabbit for G6PASE detection and goat anti-mouse antibody for $\beta$-actin). Finally, they were washed five times for $5 \mathrm{~min}$ each with TBST, and developed with BCIP/NBT (GeNei ${ }^{\mathrm{TM}}$ ). Beta actin (Ambion-
AM4302) was used as the loading control. The intensity of individual band of each immunoblot was quantified by densitometry using Image J software.

\section{CC1 hepatocytes cell culture}

The hepatocyte cells (CC-1), purchased from Sigma, were cultured and maintained in DMEM complete medium containing $10 \%(\mathrm{v} / \mathrm{v})$ fetal bovine serum, $100 \mathrm{U} \mathrm{mL}^{-1}$ penicillin, and $100 \mu \mathrm{g} \mathrm{mL} \mathrm{m}^{-1}$ streptomycin.

\section{C2C12 myoblast cell culture and differentiation}

The skeletal muscle cell line (C2C12) was obtained from Sigma. The cells were cultured in DMEM medium and differentiated to myotubes following the method as mentioned earlier. ${ }^{33}$

\section{Treatment of cells with PCA2 and high glucose (HG)}

Both the hepatocyte and myotube cells were treated with different concentrations of PCA2 $(0.02,0.05,0.1$, and $0.2 \mathrm{mg}$ $\mathrm{mL}^{-1}$ ) for $2 \mathrm{~h}$ followed by high glucose (HG, $25 \mathrm{mM}$ ) exposure for the next $20 \mathrm{~h}$.

\section{Glucose uptake study}

Glucose uptake assay was performed by using 6-[N-(7-nitrobenz2-oxa-1,3-diazol-4-yl)amino]-2-deoxy-D-glucose (6-NBDG; Invitrogen), a fluorescent analogue of 2-deoxyglucose, following a reported method..$^{34}$ Briefly, after treatment with PCA2 and HG, cells were incubated with serum-free low-glucose medium containing 6-NBDG $(20 \mu \mathrm{M})$ for $30 \mathrm{~min}$. After incubation, cells were washed with PBS, lysed with PBS containing 1\% TritonX100, and kept in dark for $10 \mathrm{~min}$. Then these were homogenized by pipetting up and down, and the plate read immediately using spectrofluorometer at excitation/emission wave lengths of $466 / 540 \mathrm{~nm}$. The results were expressed as percentage over control.

\section{Statistical analysis}

The values are presented as mean \pm SD (standard deviation) where $n=6$ or 3 . Comparisons between groups were carried out by one-way ANOVA supplemented with Dunnet's multiple comparison tests using Graphpad statistical software. Values at $P<0.05$ were considered as statistically significant.

\section{Ethical statement}

All animal procedures were performed in accordance with the Guidelines of "Committee for the Purpose of Control and Supervision of Experiments on Animals" (CPCSEA), Government of India for Care and Use of Laboratory Animals and protocol is approved by the Institutional Animal Ethical Committee (IAEC) vide approval no. IBSD/IAEC/Inst./NPC/22. The committee comprises Director of the Institute, CPCSEA main nominee, CPCSEA link nominee, Expert Scientist from outside the Institute, Veterinarian, Socially aware nominee, two members from the host institute. 


\section{Conflicts of interest}

There are no conflicts of interest to declare.

\section{Abbreviations}

$\begin{array}{ll}\text { DM } & \text { Diabetes mellitus } \\ \text { DMSO } & \text { Dimethylsulfoxide } \\ \text { WG } & \text { Wendlandia glabrata } \\ \text { PCA2 } & \text { Procyanidin A2 } \\ \text { PNPG } & p \text {-Nitrophenyl- } \alpha \text {-D-glucopyranoside } \\ \text { STZ } & \text { Streptozotocin } \\ \text { G-6-Pase } & \text { Glucose-6-phosphatase } \\ \text { G-6-P } & \text { Glucose-6-phosphate } \\ \text { cDNA } & \text { Complementary deoxyribonucleic acid } \\ \text { WHO } & \text { World Health Organization } \\ \text { IDF } & \text { International Diabetes Federation } \\ \text { SRL } & \text { Sisco Research Laboratory }\end{array}$

\section{Acknowledgements}

The authors are thankful to the Director, IASST Guwahati, CSIRNEIST Jorhat and IBSD Imphal for providing necessary facilities to carry out part of this works. We deeply acknowledged Department of Biotechnology, Ministry of Science and Technology, Govt. of India for financial support, Project No. BT/ PR24712/NER/95/828/2017. Also authors acknowledged Dr B. C. Pal, Dr B. Achari, Zeeshan Ahmad Khan for valuable suggestions.

\section{References}

1 IDF Diabetes Atlas 2017.

2 L. Chen, D. J. Magliano and P. Z. Zimmet, Nat. Rev. Endocrinol., 2012, 8, 228.

3 Y. Zhao, M. X. Chen, K. T. Kongstad, A. K. Jäger and

D. Staerk, J. Agric. Food Chem., 2017, 65, 4421.

4 U. Ghani, Eur. J. Med. Chem., 2015, 103, 133-162.

5 M. Csala, E. Margittai, S. Senesib, A. Gamberucci, G. Banhegyi, J. Mandl and A. Benedetti, FEBS Lett., 2007, $\mathbf{5 8 1}, 1693$.

6 H. Lyall, A. Grant, H. M. Scott and A. Burchell, Biochem. Soc. Trans., 1992, 20, 27IS.

7 Z. Liu, E. J. Barret, A. C. Dalkin, A. D. Zwart and J. Y. Chou, Biochem. Biophys. Res. Commun., 1994, 205, 680.

8 D. Argaud, Q. Zhang, W. Pan, S. Maita, S. J. Pilkis and A. Lange, Diabetes, 1996, 45, 1563.

9 S. Yoirentomba and P. K. Singh, Flora Fauna, 2007, 13, 355.

10 J. Y. Yumnam and O. P. Tripathi, Indian J. Tradit. Know., 2012, 11, 45 .
11 Y. Sheikh, B. C. Maibam, D. Biswas, S. Laisharm, L. Deb, N. C. Talukdar and J. C. Borah, J. Ethnopharmacol., 2015, 171, 37.

12 K. J. M. Abesundara, T. Matsui and K. Matsumoto, J. Agric. Food Chem., 2004, 52, 2541.

13 R. Mata, S. Cristians, S. Escandon-Rivera, K. Juarez-Reyes and I. Rivero-Cruz, J. Nat. Prod., 2013, 76, 468.

14 D. S. Tawfik, Nat. Chem. Biol., 2010, 6, 692.

15 A. Burchella and I. D. Waddell, Biochim. Biophys. Acta, 1991, $1092,129$.

16 G. Mithieux, H. Vidal and C. Zitoun, Diabetes, 1996, 45, 891.

17 R. C. Nordlie and K. A. Sukalski, The Enzymes of Biological Membranes, ed. A. N. Martonosi, Plenum Press, New York USA, 1985, p. 349.

18 X. Li, Y. Sui, S. Li, B. Xie and Z. Sun, J. Funct. Foods, 2016, 27, 711.

19 A. Rodriguez-Mateos, C. Heiss, G. Borges and A. Crozier, J. Agric. Food Chem., 2014, 62, 3842.

20 U. Lewandowska, K. Szewczyk, E. Hrabec, A. Janecka and S. Gorlach, J. Agric. Food Chem., 2013, 61, 12183.

21 A. Ahangarpour, G. Afshari, S. A. Mard, A. Khodadadi and M. Hashemitabar, J. Physiol. Pharmacol., 2016, 67, 243.

22 J. Reed, Crit. Rev. Food Sci. Nutr., 2002, 42 (3 suppl.), 301.

23 F. M. Steinberg, M. M. Bearden and C. L. Keen, J. Am. Diet. Assoc., 2003, 103, 215.

24 D. Bagchi, M. Bagchi, S. J. Stohs, D. K. Das, S. D. Ray, C. A. Kuszynski, S. S. Joshi and H. G. Pruess, Toxicology, 2000, 148, 187.

25 K. J. Murphy, A. K. Chronopoulos, I. Singh, M. A. Francis, H. Moriarty, M. J. Pike, A. H. Turner, N. J. Mann and A. J. Sinclair, Am. J. Clin. Nutr., 2003, 77, 1466.

26 L. Y. Foo, Y. Lu, A. B. Howell and N. Vorsa, J. Nat. Prod., 2000, 63, 1225.

27 S. Laisharm, Y. Sheikh, D. S. Moirangthem, L. Deb, B. C. Pal, N. C. Talukdar and J. C. Borah, Phytomedicine, 2015, 22, 23.

28 L. G. Luna, Manual of Histology Staining Methods of Armed Forces Institute of Pathology, Blakiston Division, McGrawHill, 1968, New York, 3rd edn.

29 S. S. Im, M. Y. Kim, S. K. Kwon, T. H. Kim, J. S. Bae, H. Kim, K. S. Kim, G. T. Oh and Y. H. Ahn, J. Biol. Chem., 2011, 286, 1157-1164.

30 K. J. Livak and T. D. Schmittgen, Methods, 2001, 25, 402.

31 R. Tang, A. Dodd, D. Lai, W. C. McNabb and D. R. Love, Acta Biochim. Biophys. Sin., 2007, 39, 384.

32 A. Chattoraj, S. Bhattacharyya, D. Basu, S. Bhattacharya and S. K. Maitra, Gen. Comp. Endocrinol., 2005, 140, 145.

33 S. Y. Shi, S. Y. Lu, T. Sivasubramaniyam, X. S. Revelo, E. P. Cai and C. T. Luk, Nat. Commun., 2015, 6, 7415.

34 P. Manna and S. K. Jain, J. Biol. Chem., 2012, 287, 42324. 